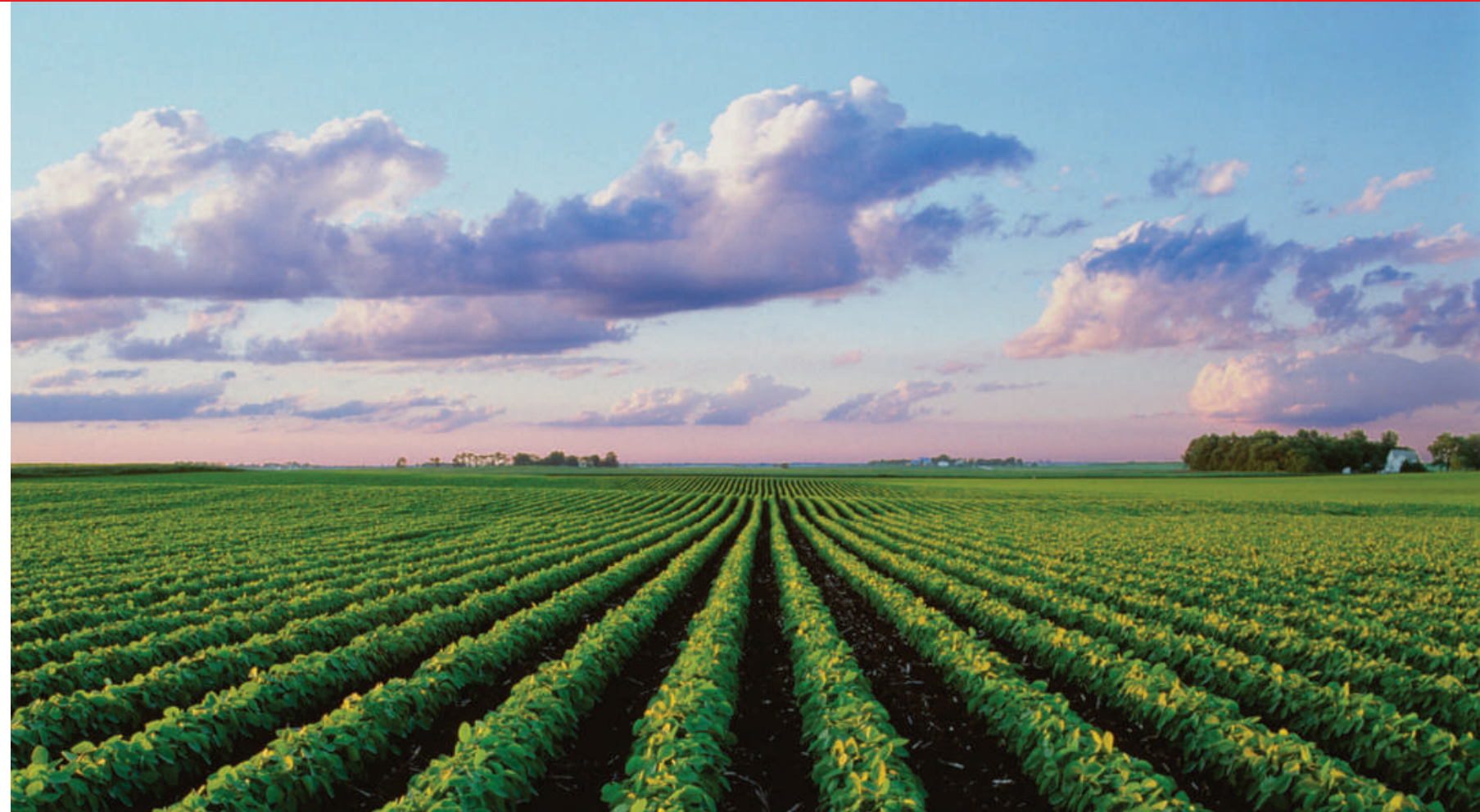

\title{
US agriculture research gets priority plan
}

\section{Federal restructuring aims to lessen the influence of pork-barrel politics.}

US agricultural research is getting a makeover. The National Institute of Food and Agriculture (NIFA) opens its doors on 1 October, with plant biotechnologist Roger Beachy at its helm.

Many scientists hope that the new institute will improve the focus, effectiveness and visibility of basic agricultural research, long criticized for being driven by regional politics instead of national priorities. But it's too early to tell how big an impact NIFA will have.

"Overall, there's been a negative perception of agriculture research, especially on [Capitol] Hill," says Beachy, founding president of the non-profit Donald Danforth Plant Science Center in St Louis, Missouri. "This is an opportunity to re-evaluate the role of research and research organization."

The institute is part of a major reshuffle at the US Department of Agriculture (USDA), which in April enlisted health and agriculture specialist Rajiv Shah as the department's first chief scientist. Both Shah and his boss, agriculture secretary Tom Vilsack, have stressed the importance of basic agriculture research in addressing national and global needs, including climate change, biofuels, nutrition, and food safety and security.

Yet Beachy's arrival also underscores the often-close ties between US agribusiness and federal research. At Washington University in St Louis in the 1980s, Beachy worked on virus resistance in plants, and later collaborated closely with Monsanto, the leading producer of genetically engineered seed, on transgenic crops. The Danforth Center was founded with grants from Monsanto's philanthropic arm among others, and the president and chief executive of Monsanto is on the centre's board of trustees. It was also Bill Danforth, the centre's founder, who originally proposed NIFA in 2004 when he was chair of a USDA task force; Congress approved it in 2008.

Ignacio Chapela, an environmental scientist at the University of California, Berkeley, worries that such close industry links might result in narrow-minded policies. "Imprinting NIFA with such a clearly biased character is likely to exacerbate the discredit of US policy-making bodies in a national and international environment," he argues.

But unless the country sets unified national goals in awarding research grants, Danforth says, agriculture will continue to lose out, as it did in the economic stimulus package passed by Congress in February. "The National Institutes of Health got $\$ 10$ billion, the National Science Foundation got $\$ 3$ billion and agriculture got zip," he says. "The reason in my view is sophisticated people thought the money would be wasted, and deservedly so, because too much went to pork."

Beachy says he hopes that NIFA and its competitive grants programme, the Agriculture and Food Research Initiative (AFRI), will cut back on congressional demands to earmark funds for specific projects. One big question will be their budget: in the current fiscal year, AFRI received just over $\$ 200$ million, although that figure could reach $\$ 295$ million for next year if numbers being worked through in congressional committees hold up. Beachy eventually hopes for $\$ 700$ million annually.

Despite its ambitious goals, NIFA's ultimate impact is uncertain.

"It's hard to know what's going to happen," says animal scientist Jim Ireland at Michigan State University in East Lansing, who has called for more funding for agriculture research, particularly for farm animals. "It's good to see that they have new people, but the budget's a problem they're going to be facing regardless of how smart they are."

Animal scientist Michael Roberts, who was chief scientist of a previous USDA grantgiving body from 1998 to 2000, is also cautious. "It seems like there hasn't been a great deal of change, except for the name," he says. "This is a new organization that seems to be operating on a similar budget as the previous organization." But Beachy might have more political influence because of the structure of the new position, Roberts says: "He's a good scientist, very well respected and pretty savvy politically." Lizzie Buchen 